\title{
Beyond NK cells: the expanding universe of innate lymphoid cells
}

\author{
Marina Cella*, Hannah Miller and Christina Song \\ Department of Pathology and Immunology, Washington University School of Medicine, St. Louis, MO, USA
}

Edited by:

Massimo Vitale, IRCCS

A.O.U.S.Martino-IST, Italy

Reviewed by:

Andreas Diefenbach, University of

Freiburg, Germany

Aharon Freud, Ohio State University,

USA

\section{*Correspondence:}

Marina Cella, Department of

Pathology and Immunology,

Washington University School of

Medicine, BJCIH Room 8107, 425

South Euclid, St. Louis, MO 63110,

USA

e-mail:mcella@pathology.wustl.edu
For a long time, natural killer (NK) cells were thought to be the only innate immune lymphoid population capable of responding to invading pathogens under the influence of changing environmental cues. In the last few years, an increasing amount of evidence has shown that a number of different innate lymphoid cell (ILC) populations found at mucosal sites rapidly respond to locally produced cytokines in order to establish or maintain homeostasis. These ILC populations closely mirror the phenotype of adaptive T helper subsets in their repertoire of secreted soluble factors. Early in the immune response, ILCs are responsible for setting the stage to mount an adaptive $T$ cell response that is appropriate for the incoming insult. Here, we review the diversity of ILC subsets and discuss similarities and differences between ILCs and NK cells in function and key transcriptional factors required for their development.

Keywords: innate lymphoid cells, IL-22, NKp44, cytokines, mucosal tissues

\section{INTRODUCTION}

The adaptive immune system has evolved antigen receptor diversity to cope with a large variety of pathogens and non-self antigens. It is well-established that, depending on the nature of the invader and the signals coming from the surrounding environment, the adaptive immune system mounts a specific effector $\mathrm{T}$ helper (Th) response that serves to control the trespasser and re-establish homeostasis. Functionally, Th1 eliminate intracellular pathogens, Th2 are critical in promoting the eradication of helminthes, and Th17 control fungal and bacterial infections (1).

In the last few years, it has become evident that the innate immune system displays a similar strategy in order to ensure a first line of defense against intruders via innate lymphoid cells (ILCs). Broadly, ILCs are defined by their lymphoid lineage and their lack of RAG-mediated recombined antigen receptors. Mirroring the Th subsets, ILC populations diverge from one another in their reliance on unique transcription factors and production of signature cytokines. In general, ILCs provide primary border patrol at mucosal surfaces sensing changes in the microenvironment and rapidly responding to insults by producing specific cytokines that limit the damage caused by the attacking pathogen or favor its clearance and elimination.

Until ILCs came into the spotlight, conventional NK cells (cNKs) (i.e., blood circulating $\mathrm{CD}^{+} 6^{+}$cells in human and splenic, lymph node, and bone marrow $\mathrm{NKp} 46^{+} \mathrm{NK} 1.1^{+}$cells in mouse) were the only innate immune cells known to respond to cytokines produced by antigen presenting cells (APCs), such as dendritic cells (DCs) and macrophages (2-4).

Natural killer (NK) cells can rapidly release IFN- $\gamma$ in response to IL-12 and IL-18 and/or type 1 IFN, which are produced when viruses and bacteria infect or come into contact with APCs. Because of their capacity to immediately respond to cytokines, cNK cells can be viewed as the prototype of all ILC subsets.
However, they have additional properties, such as cytotoxic ability, that set them apart from other ILCs and allow them to eliminate virally infected or tumor-transformed cells.

Here, we will review the lineage relationship between ILC subsets and cNKs based on key transcription factors that regulate their respective development as well as the current understanding their functional roles.

\section{ILC HETEROGENEITY AND FUNCTIONAL SPECIALIZATION}

Innate lymphoid cells, like Th cells, are heterogeneous and currently grouped in three major subsets: ILC1, ILC2, and ILC3 (5).

\section{GROUP 1 ILCs}

ILC1s produce the Th1 signature cytokine IFN- $\gamma$. They include cNK [reviewed in detail in Ref. $(6,7)$ ] and several additional, recently described, subsets of IFN- $\gamma$-producing cells (8-10) (Table 1).

\section{A brief overview of cNK cells}

Conventional NK cells have been known and actively studied for almost four decades $(11,12)$. cNKs were first described as a cell subset capable of rapidly eliminating tumor-transformed or allogeneic cells without the need for prior sensitization and in the absence of RAG-recombined antigen receptor recognition $(13,14)$. Traditionally, cNK cells are thought to be critical in conferring protection from viral infections, such as CMV (15), and in the immunosurveillance of tumor-transformed cells $(16,17)$.

In humans, cNKs include the $\mathrm{CD} 56^{\text {bright }} \mathrm{CD} 16^{-}$and the CD56 ${ }^{\mathrm{dim}} \mathrm{CD} 16^{+}$subsets present in peripheral blood. CD56 bright NK cells are specialized in IFN- $\gamma$ secretion in response to DCs/macrophages-derived cytokines, such as IL-12 and IL-18 (18) or T cell-derived cytokines, such as IL-2 (19), a functional feature 
Table 1 | Emerging subsets of ILC1 and tissue-resident NKs.

\begin{tabular}{|c|c|c|c|c|c|c|c|}
\hline & CD127 & $\begin{array}{l}\text { IL-15 } \\
\text { dependence }\end{array}$ & $\begin{array}{l}\text { IL-7 } \\
\text { dependence }\end{array}$ & $\begin{array}{l}\text { TBX21 } \\
\text { dependence }\end{array}$ & $\begin{array}{l}\text { Eomes } \\
\text { dependence }\end{array}$ & $\begin{array}{l}\text { E4BP4 } \\
\text { dependence }\end{array}$ & Human counterpart \\
\hline siLP ILC1 & +++ & Yes & No & Yes & No & Partial & $\begin{array}{l}\text { Most likely } \\
\mathrm{CD}^{2} 27^{+} \mathrm{CD}^{-} 6^{-} \mathrm{CD}^{-} \\
\text {mucosal cells }\end{array}$ \\
\hline Intraepithelial ILC1 & - & Partial & No & Yes & TBD & Yes & $\begin{array}{l}\mathrm{CD} 56^{+} \mathrm{NKp} 44^{+} \\
\mathrm{CD} 103^{+} \mathrm{CD} 160^{+} \text {cells in } \\
\text { human tonsil and intestine }\end{array}$ \\
\hline $\begin{array}{l}\text { "Converted" or } \\
\text { "plastic" ILC3 }\end{array}$ & +++ & $\begin{array}{l}\text { No, but IL-15 can } \\
\text { promote } \\
\text { conversion }\end{array}$ & Yes & Yes & No & TBD & Mostly generated in vitro \\
\hline $\begin{array}{l}\text { Liver-resident } \\
\text { CD49a+DX5- NKs/ILC1 }\end{array}$ & - & Yes & TBD & Yes & No & No & TBD \\
\hline $\begin{array}{l}\text { Skin-resident } \\
\text { CD49a+DX5- NKs }\end{array}$ & - & Yes & TBD & Yes & TBD & No & TBD \\
\hline $\begin{array}{l}\text { Uterus-resident } \\
\text { CD49a+DX5- NKs }\end{array}$ & - & Yes & TBD & No & TBD & No & TBD \\
\hline Salivary gland NKs & - & Yes & TBD & TBD & TBD & No & TBD \\
\hline
\end{tabular}

$T B D$, to be determined.

that place them close to other ILC1 subsets. $\mathrm{CD} 56^{\mathrm{dim}} \mathrm{CD} 16^{+} \mathrm{NKs}$ are specialized in cytotoxicity, since they can readily release lytic granules containing perforin and granzyme upon contact with sensitive targets. However, it has been shown that also CD56 dim NK cells can produce IFN- $\gamma$, although with a more rapid kinetic and in a less sustained fashion than CD56 $6^{\text {bright }}$ NKs (20). In addition, it has been suggested that CD56 $6^{\text {bright }}$ can differentiate into CD56 ${ }^{\mathrm{dim}}$ NKs upon activation $(21,22)$. CD $56^{\text {bright }}$ cells produce additional monokines such as GM-CSF, TNF- $\alpha$, IL-13, and IL-10, suggesting that they may exert an immunoregulatory function in specific circumstances (23). In addition, CD56 ${ }^{\text {bright }} \mathrm{NKs}$ express CCR7, CXCR3, and CD62L and they are thought to traffic to secondary lymphoid organs via high endothelial venules (HEVs) (24).

In mouse, cNK include mature $\left(\mathrm{CD} 11 \mathrm{~b}^{\text {high }} \mathrm{CD} 27^{\text {low }}\right)$ and immature $\left(\mathrm{CD} 27^{\text {high }} \mathrm{CD} 11 \mathrm{~b}^{\text {low }}\right)$ circulating splenic and bone marrow NKs (25), CD127 ${ }^{+}$(the IL-7 receptor $\alpha$ chain) IL-7-dependent thymic-derived NKs (26), and different subsets of tissue-resident NKs $(12,27)$ whose nature, function, and relationship to other emerging subsets of ILC1 we are just beginning to understand. Tissue NKs include an abundant population of salivary gland NKs, which are poorly cytotoxic and poor producers of cytokines $(28,29)$, liver-resident CD49a ${ }^{+}$(VLA1) DX5 ${ }^{-}$NK cells, and skinand uterus-resident NK cells (30). Thymic NKs for their ability to produce IFN- $\gamma$, TNF- $\alpha$, and GM-CSF in response to IL-12 are thought to represent the murine counterpart of human CD56 bright NK cells. One unifying feature of all NK cell subsets, including thymic NKs (31), is their dependence on IL-15 and IL-15R $\alpha$ for development, survival, and maintenance.

The major breakthrough in understanding the biology and function of cNK cells was the discovery of germ line-encoded cell surface receptors of the C-type lectin or of the immunoglobulin superfamily that deliver either inhibitory or activating signal to NK cells $(3,32-35)$. These receptors, some of which are clonally distributed, finely tune NK cytolytic ability and the capacity to release cytokines through recognition of MHC class I molecules or other counter-receptors specifically expressed by target cells upon infection, tumor transformation, or stress-related signals (36). The appreciation of the complex array of signaling receptors expressed by cNKs has challenged the idea that NK cells simply exert "natural" cytotoxicity, and has suggested that in addition to "missing self" (37), which leads to release of inhibition mediated by inhibitory receptors that recognize self MHC class I, NK cells have to integrate a complex network of clues, which depend on contact with the target cells and/or the surrounding microenvironment. Accordingly, recent work has suggested that engagement of cytokine receptors can influence NK cell recognition mediated by activating receptors, such as NKG2D (38). Importantly, expression of inhibitory and activating receptors on NK cells controls their education and "licensing" (39), as well as 
their expansion during responses to pathogens. This expansion generates a long lived-memory-type NK cell progeny that is more effective in clearing infections upon a second challenge $(6,40)$.

Thus cNK cells possess some features adaptive immune cells that maximize their capacity to eliminate intruders while avoiding self-reactivity (7).

\section{Emerging ILC1 subsets}

One first subset of ILC1 is present in human mucosal tissues and expresses CD127 and the C-type lectin CD161, but does not express other markers of the NK lineage such as CD94, CD56, NKp44 (NCR2), or NKp46 (NCR1); although it rapidly responds to IL-12 and IL-18 by producing IFN- $\gamma(8)$. These cells also do not express c-kit (the receptor for stem cell factor, SCF), which marks many other ILC subsets.

The second subset was identified in human tonsillar tissue and is characterized by the expression of several NK-related markers such as CD56, NKp46, and NKp44 (9). However, this subset also expresses markers of tissue-resident memory CD8 T cells such as CD103, CD49a, and CD101. These ILC1s are also present in mouse small intestine, have an intraepithelial location, and are distinguished by the expression of CD160, a receptor of the immunoglobulin superfamily that binds to the TNF receptor superfamily member HVEM. HVEM-CD160 interactions promote epithelial integrity by inducing the alternative NF-kB signaling pathway and Stat3 phosphorylation in epithelial cells (41). Intraepithelial resident ILC1s are distinguished by $\mathrm{cNKs}$ because they do not respond to IL-12 and IL-18. Alternatively, they secrete large amounts of IFN- $\gamma$ upon stimulation with IL-15. Notably, intraepithelial ILC1s are only partially dependent on IL-15/IL$15 \mathrm{R} \alpha$ signaling for their development, a feature that set them apart from cNKs. Interestingly, these ILC1s seem to promote tissue damage in a mouse model of colitis induced by CD40 ligation in immune-deficient mice. Although the function of the newly described human ILC1 subsets has not been investigated in detail in vivo, they may play important pathogenic roles in human inflammatory bowel diseases (IBDs) as both $\mathrm{CD}^{-} 6^{-} \mathrm{CD} 127^{+}$and $\mathrm{NKp} 44^{+} \mathrm{CD} 103^{+}$ILC1s are increased in patients with Crohn's disease, as compared to control individuals $(8,9)$. For instance, earlier studies have suggested that IL-15 and retinoic acid are highly pathogenic factors in celiac disease, since they induce production of IL- 12 by intestinal DCs (42). In light of the fact that one ILC1 subset is responsive to IL-12, while the other promptly reacts to IL-15, it would be interesting to explore the respective role of these ILC1 subsets in human celiac disease or mouse models of celiac disease.

A putative murine equivalent of the $\mathrm{CD}^{5} 6^{-} \mathrm{CD} 127^{+}$human ILC1s has been recently described in small intestine lamina propria (siLP) (10). These cells are CD127 ${ }^{+}$, but also express markers of the NK lineage, such as NKp46 and NK1.1. Interestingly, siLP ILC1s, as cNKs, depend on IL-15, but not IL-7, for their development. In vivo these cells are major producers of IFN- $\gamma$ and TNF- $\alpha$ in response to oral infection with Toxoplasma gondii (T. gondii) and promote clearance of this pathogen by recruiting inflammatory monocytes through the CCR1/CCL3 axis (43). Therefore, in these settings, siLP ILC1s play a major protective role. Most likely, clearance of T. gondii requires a strong Th1 environment, while in Crohn's disease a robust Th1 signature sustains autoimmune damage and tissue destruction, explaining why ILC1s may play protective or pathogenic roles in different scenarios and in different diseases.

Another subset of ILC1s is represented by the so-called "converted" or "plastic" ILC3s. These cells can be generated in vitro from ILC3s in response to cytokines such as IL-15, IL-2, IL-12, and IL-23 that induce IFN- $\gamma$ production $(8,44)$. They can also be induced in vivo by transfer of ROR $\gamma \mathrm{t}^{+}$ILC3s and visualized by fate-mapping experiments in $\operatorname{siLP}(10,45,46)$.

\section{GROUP 2 ILCs}

ILC2s produce the Th2 signature cytokines IL-5 and IL-13 (47-50). They also produce amphiregulin and IL-9, and notably, IL-9/IL9 receptor signaling is required for their survival (51). ILC2s are found in various tissues including adipose tissue-associated lymphoid structures, gut, lung (52) and, as recently described, the skin (53-55). They promote expulsion of parasites $(56,57)$ and maintain lung homeostasis (58) or drive airway hyper-reactivity during viral infections, such as influenza (59). They also contribute to the pathogenesis of atopic dermatitis (53-55). In visceral adipose tissue, ILC2s maintain metabolic homeostasis by recruiting eosinophils, which sustain macrophage alternative activation (60, 61). ILC2s rapidly respond to the alarmin IL-33, to the IL-17 family member IL-25 and to TSLP in skin (62). They are characterized by the expression of CD127, c-kit, Scal, and ST2 (the receptor for IL-33). Human ILC2s express CD161 and high levels of the prostaglandin D2 receptor CRTH2 (63). Notably, ILC2s are highly enriched in nasal polyps of patients with chronic rhinosinusitis (63), suggesting that they might play a fundamental role in human Th2-mediated diseases such as asthma and atopic dermatitis. A subset of cells named multipotent progenitor type 2 (MPPtype2), originally classified within ILC2s because of their ability to expand in response to IL-25, have been recently shown to contain progenitors giving rise to myeloid cells, such as macrophages and eosinophils (50). Because of the distinct transcriptional profile and functional potential that distinguishes MPP ${ }^{\text {type2 }}$ from other ILC2s, and ILCs in general, these cells are no longer classified as Group 2 ILCs.

\section{GROUP 3 ILCs}

ILC3s produce the Th17 signature cytokines IL-17 and/or IL-22 (64-69). ILC3s include Lineage ${ }^{-}$(Lin)ROR $\gamma \mathrm{t}^{+} \mathrm{CD}^{+}{ }^{+}$Lti-like cells originally described in the 1990s (70), $\mathrm{Lin}^{-} \mathrm{ROR} \gamma \mathrm{t}^{+} \mathrm{CD} 4^{-} \mathrm{Lti}-$ like cells, $\mathrm{NCR}^{+}$ILC3s originally named NK-22 (65), and colonic Sca ${ }^{+}$Thy $1^{\text {high }}$ ILCs (71). ILC3s rapidly respond to IL-23, a member of the IL-12 family. They also express the IL-1 receptor and respond to IL- $1 \beta(44,72)$. ILC3s are mainly found in mucosal tissues, such as small and large intestine, Peyer's patches (PP), and gut-associated lymphoid tissue (GALT). Small numbers of ILC3s are present in spleen (73) and lung (74). By producing IL-22, ILC3s protect intestinal epithelium in vivo from attaching and effacing bacteria, such as Citrobacter rodentium, a mouse model of human enteropathogenic E. coli (75). IL-22 acts selectively on stromal and epithelial cells by inducing STAT3 phosphorylation, leading to multiple downstream events including the rapid production of the antimicrobial peptides alpha and beta defensins, as well as the promotion of epithelial cell survival and proliferation 
$(75,76)$. ILC3s and ILC3-derived IL-22 are critical in containing dissemination of commensal bacteria in immune-deficient animals. In the absence of ILC3s, host-derived bacteria of the Alcaligenes species disseminate to peripheral organs and induce systemic inflammation (77). IL-22 also acts on intestinal epithelial stem cells, and radio-resistant IL-22-producing ILC3s from the recipient are key to limit the severity of intestinal damage during graft versus host disease (GVHD) (78).

While in the short term IL-22-mediated survival and proliferation of epithelial cells may favor tissue healing and repair, prolonged IL-22 signaling, and sustained epithelial proliferation may drive tumor formation (79). Accordingly, recent evidence has linked colonic ILC3s to colon cancer in a genetically prone bacterial-driven model of colon cancer (80). ILC3s have also been involved in other human disease, such as Crohn's disease (81) and psoriasis (82).

$\mathrm{NCR}^{-}$ILC3s have been shown to negatively regulate adaptive CD4 T cell responses to commensals. This process does not depend on IL-17 or IL-22 but requires MHC class II expression on ILC3s and, by mechanisms yet to be completely elucidated, restricts CD4 $\mathrm{T}$ cell proliferation to commensal antigens (83).

Interestingly, in human tonsil, ILC3s produce GM-CSF, BAFF, and LIF in addition to IL-22 and express high levels of CD40L and RANKL (44). GM-CSF promotes accumulation of granulocytemonocyte progenitors (GMPs) and mediates immunopathology in a mouse model of T cell-mediated colitis (84). Surprisingly, in steady state conditions, ILC3-derived GM-CSF is essential to induce development of $\mathrm{CD}_{103^{+}} \mathrm{CD}_{11 \mathrm{~b}}{ }^{+}$DCs that instruct differentiation of FoxP3 ${ }^{+}$Treg cells in an IL-10, TGF- $\beta$, and retinoic acid-dependent fashion. ILC3s produce GM-CSF selectively upon stimulation with IL- $1 \beta$, which is released by macrophages activated by microbial products (85). Selective loss of GM-CSF in ILC3s results in impaired oral tolerance to dietary antigens.

CD40L expression and BAFF production by ILC3s enhance antibody secretion by marginal zone B (MZB) cells (86). Interestingly, ILC3s activate marginal reticular cells (MRCs) by providing TNF- $\alpha$ and lymphotoxin (LT). They also receive survival signals from MRCs, including IL-7. The interaction between MZB cells and ILC3s also involves expression of DLL1 by ILC3s, a Notch ligand that may activate Notch2 on MZB cells (86). Furthermore, in these settings, GM-CSF produced by ILC3s promotes APRIL secretion by neutrophils, boosting their B helper phenotype and further promoting IgM, IgG, and IgA production by MZB cells. ROR $\gamma \mathrm{t}^{+}$ LTi-like ILC3s induce T cell-independent IgA production in isolated lymphoid follicles (ILFs). The simultaneous stimulation of stromal cells by LTi-like cells, via LT/LT $\beta$ R, and by bacteria, via TLRs, induces recruitment of DCs and B cells promoting formation of ILFs and boosting T cell-independent IgA production in ILFs (87). Type 3 ILCs have also been shown to control T celldependent IgA production through release of soluble LT $\alpha 3$, which induces $\mathrm{T}$ cell homing to the gut (88). Ultimately, reduction in IgA levels due to absence or dysfunction of ILC3s in small intestine will induce changes in the microbial communities that may cause immunopathology. Collectively, these studies indicate that ILC3s may provide help to B cell responses at mucosal barriers by multiple mechanisms that may cooperate in providing optimal protection from environmental insults.
The relevance of LIF production and RANKL expression by ILC3s has yet to be understood. However, RANKL has been shown to be essential for the differentiation of the specialized microfold cells ( $M$ cells) that overlay the dome region of PP (89). Therefore, RANKL expression by ILC3s could be relevant in the context of PP function and biology and in the transport of particulate antigen from the lumen to APCs located in the sub-epithelial dome area of PP.

Although a transient burst of IL-22 from ILC3s seems to play protective effects in many scenarios and in particular during bacterial infections, a recent study has defied this view. IL-22 induces robust expression of antimicrobial proteins, such as lipocalin and calprotectin. These proteins are known to sequester metal ions including iron, zinc, and manganese. By subtracting these ions to commensal bacteria, IL-22 favors expansion of pathogenic bacteria, such as Salmonella typhimurium that are resistant to ion starvation (90). Therefore, in some circumstances, ILC3s may tip the balance in favor of pathogens, rather than protect from their attack.

In addition to sensing cytokines released in the surrounding microenvironment, ILC3s are also sensitive to nutrients. Recent work has shown that vitamin A deficiency results in decreased numbers of ILC3s in the intestine, which increases susceptibility to bacterial infections. However, the same deficiency induces expansion of ILC2s, which protect from nematode infections (91). Moreover, vitamin A intake by pregnant mothers controls the pool of LTi-like CD4 ${ }^{+}$ILC3s in embryos, the size of lymph nodes and $\mathrm{PP}$, and the efficacy of immune responses to viral infections (92). These findings again emphasize the idea that ILCs are exquisitely sensitive to environmental cues and continuously adapt to rapidly changing settings, such as the ones present at mucosal surfaces.

\section{THE NETWORK OF MASTER REGULATORS OF ILC DEVELOPMENT}

Until recently, the general consensus was that the very same transcription factors that drive Th1, Th2, and Th17 commitment and differentiation also regulate ILC1, ILC2, and ILC3 development, respectively. Moreover, it seemed that $\mathrm{cNKs}$ and the other ILC groups significantly differed in their developmental requirement for transcription factors.

This concept has been recently challenged by a number of studies suggesting that developmental requirements for NK cell subsets and ILCs are more complex than originally anticipated (Figure 1). Here, we will highlight the most recent progresses in the field.

All ILC groups, including cNKs, depend on Id2 (47, 93). Id 2 is a transcriptional repressor that, by blocking members of the E2 family of transcription factors, suppresses the B cell fate potential in a progenitor cells that develop downstream of the common lymphoid precursor (CLP). A recent study that took advantage of a reporter mouse expressing GFP under the control of the Id 2 promoter to track Id2-expressing cells has shown that Id 2 is not expressed in CLPs. Id2 is, however, expressed at very high level in all ILCs, including cNKs (94). In NK cells, Id2 is not required for the NK cell lineage specification, since development of $\mathrm{CD} 122^{+} \mathrm{NK} 1.1^{-} \mathrm{NK}$ cell progenitors is not impaired in Id2deficient mice. Nevertheless, Id 2 expression in NK cells is required for acquisition of a fully mature phenotype. The few NK cells that 


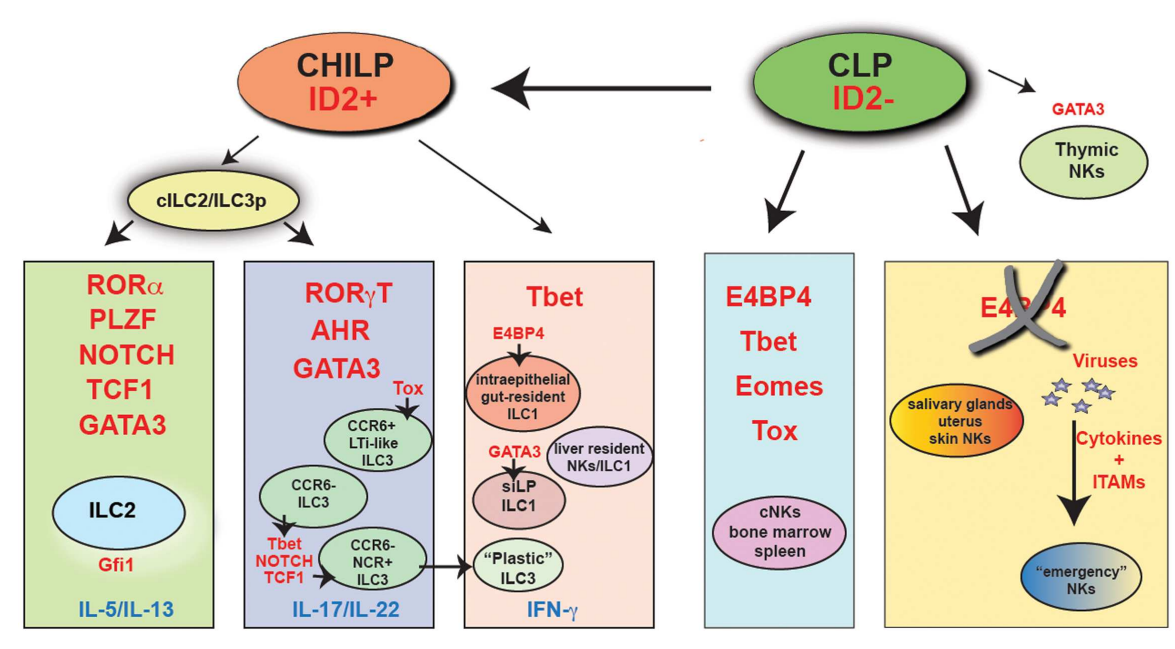

FIGURE 1 |The major transcriptional pathways that control ILC and NK cell development. Indicated in red are the key transcription factors that have been shown being absolutely required in vivo for the development of each cell subset. "Emergency" NK cells are NK cells that develop in the absence of E4BP4, following viral infection. It is presently unclear whether these cells are Tbet-dependent. CHILP, common helper innate lymphoid precursor; CLP, common lymphoid progenitor; cILC2/ILC3p, common ILC2/ILC3 progenitor. develop in the absence of Id 2 have a phenotype that closely resemble thymic NK cells, express high levels of CD127 and produce large amounts of IFN- $\gamma$ (95). In committed B cells, the transcription factor EBF1 mediates Id2 suppression (96). According to the idea that Id2 is globally required for development of all ILCs, EBF1-deficient pro-B cells acquire the capacity to differentiate into $\mathrm{T}$ cells and into functionally competent ILC2s and ILC3s (97). Importantly, the generation of an Id2-reporter mouse has allowed the identification of a common ILC progenitor, or CHILP (common "helper-like" ILC lineages progenitor) (10) that can generate $\mathrm{CD} 127^{+} \mathrm{NKp} 46^{+}$siLP ILC1, ILC2, and ILC3 in vivo and in vitro. This $\mathrm{Lin}^{-} \mathrm{Id} 2^{+}$progenitor also expresses CD127 and the integrin $\alpha 4 \beta 7$ but does not express CD25 (which is present on differentiated ILC2) or CD122, a marker of NK cell precursors. Intriguingly, this precursor is only slightly affected by IL-7 deficiency and can generate liver-resident CD49a ${ }^{+}$Eomes $^{-}$NK cells, but not cNKs (10). Further confirming the existence of a common ILC progenitor, an other recent study performing fate-mapping experiments shows that ILCs, including intraepithelial ILC1, ILC2, and $\mathrm{NCR}^{+}$ILC3, derive from a common committed precursor present in fetal liver and adult bone marrow that transiently expresses the transcription factor PLZF (encoded by Zbtb16) (98). This transcription factor was known to be required for NKT development, but it is dispensable for cNK cells and CD4 ${ }^{+}$LTi-like cells (99). Reconstitution experiments with Zbtb16-deficient or sufficient bone marrow cells in lethally irradiated mice indicated that $Z b t b 16$ is absolutely required for ILC2s development only. On the contrary, it seems to be dispensable for $\mathrm{NCR}^{+}$ILC3s reconstitution, despite its high expression in this subset. As Zbtb16 is controlled by Id2 (100), the PLZF-expressing common ILC precursor may be downstream of the $\mathrm{Id} 2^{+} \mathrm{CD} 127^{+} \mathrm{CD} 25^{-} \alpha 4 \beta 7^{+}$ CHILP.

Most likely downstream of the CHILP, all ILC3 subsets require the Th17 master regulator $\operatorname{ROR} \gamma \mathrm{t}(101,102)$. In the absence of ROR $\gamma \mathrm{t}$, Lti, and Lti-like cells fail to develop and ROR $\gamma \mathrm{t}$ deficient mice do not possess lymph nodes, PP, cryptopaches (CP) nor ILFs (103, 104), which derive from CP under signals coming from the microbiota through the nod-like receptor (NLR) NOD1 (105). ILC3s also require aryl hydrocarbon receptor (AHR) (106-108), which drives IL-22 secretion in Th17 cells $(109,110)$. In the absence of AHR, both Lti-like ILC3s and NCR ${ }^{+}$ ILC3s are severely diminished. In addition, small intestine CP and ILFs are absent, while colonic patches develop normally (111). Some studies have suggested that exogenously provided AHR agonists, such as tryptophan derivatives added to the diet, play a role in expanding and/or maintaining ILC3s $(106,112)$. Recent work has also shown that AHR agonists derived from commensal bacteria, such as lactobacilli, increase IL-22 production by ILC3s in the context of a tryptophan rich diet and this, in turn, confers resistance to infection by the opportunistic fungus Candida albicans (113). It is also possible that endogenous AHR ligands, such as kynurenine, produced by the enzyme tryptophan dioxygenase (TDO), may play a critical role in ILC3 biology (114).

Unexpectedly, AHR, in ILC3 cells, restrains adaptive Th17 responses. In AHR-deficient mice that lack ILC3s, Th17 cells in siLP undergo an uncontrolled expansion that leads to tissue damage. This Th17 proliferation is due to a dysregulation in the intestinal microbial niche that allows excessive growth of segmented filamentous bacteria (SFB), commensals known to drive Th17 differentiation (115).

In addition to ROR $\gamma \mathrm{t}$ and AHR, ILC3s also depend on Notch signaling for their development $(111,116)$. In $\mathrm{RBP}_{-} \mathrm{J}_{\mathrm{k}}{ }^{-1}$ mice that lack all Notch signaling, $\mathrm{NCR}^{+}$ILC3s are selectively reduced. Notch also promotes ROR $\gamma \mathrm{t}^{+}$ILC differentiation from adult bone marrow precursors (117). Recent studies have also shown that $\mathrm{NCR}^{+}$ILC3s, which develop post-natally and reach maximal expansion 4-6 weeks after birth in mouse small intestine LP (118), 
express Tbet (encoded by Tbx21) and require Tbet for development $(46,116,119,120)$. Induced by IL-23 and cues from the microbiota, Tbet is essential to instruct IFN- $\gamma$ production and protection from pathogens such as $S$. typhimurium (46). Tbet expression seems to induce Notch, as Tbet haplo-insufficiency results in reduced Notch expression (116). However, it is conceivable that AHR and Tbet may cooperate in inducing Notch and final maturation of $\mathrm{NCR}^{+}$ILC3s.

The requirement for Tbet in $\mathrm{NCR}^{+}$ILC3s is somewhat surprising since human tonsil ILC3s do not express Tbet ex vivo (44). In fact, in steady state conditions, Tbet expression is limited to ILC1s and cNKs, while ROR $\gamma \mathrm{t}$ is selectively expressed by ILC3 (9).

Human tonsil ILC3s also express high levels of CCR6 and can easily be sorted at high purity based on NKp44 and CCR6 expression $(44,121)$, while mouse $\mathrm{NCR}^{+}$ILC3s are CCR6 negative (46). Whether the discrepancies between the mouse and human system are linked to tissue specific differences (intestine versus tonsil) still remains to be determined. It is conceivable that Tbet may be needed at later stages of ILC3s differentiation, which may be poorly represented in the tonsil. In agreement with this hypothesis, tonsil ILC3s are characterized by an intrinsic plasticity and, when stimulated with cytokines such as IL-2 and IL-15 in vitro, can generate IFN- $\gamma$ producing pro-inflammatory cells that acquire some features of cNK $(8,44)$. Specific engagement of cell surface receptors expressed by ILC3s by cognate ligands present in some tissues but not in others may also be an issue. Indeed, a recent study has suggested that stimulation of ILC3s via the DAP12-associated activating receptor NKp44 induces production of TNF- $\alpha$ and convert them to a more inflammatory-prone cell type (122). Experiments in mice have suggested that ILC3 conversion to an IFN- $\gamma / \mathrm{TNF}-\alpha$ secreting pro-inflammatory cell type can occur in vivo (45). Moreover, recent fate-mapping experiments, aimed to track cells that expressed ROR $\gamma \mathrm{t}$ at any stage of their life cycle, show that "plastic" or "converted" ILC3s are present within the ROR $\gamma \mathrm{t}^{-} \mathrm{NKp} 46^{+} \mathrm{NK} 1.1^{+}$population in siLP and cluster with siLP ILC1s and CNK (10).

Finally, STAT3 expression in ILC3s is required for robust IL22 production and protection by intestinal infection with $C$. rodentium (123).

Group 2 ILCs necessitate ROR $\alpha$ (124), Gfil (125), and Gata-3 for their development $(94,125-127)$. Gfil specifically controls the response to IL-33 and TSLP and the production of IL-5, but not IL13, in ILC2s (125). The requirement for Gata-3 by ILC2s closely resembles the need for Gata-3 in Th2 differentiation. However, Gata-3 is also necessary for thymic NK cell development (26). Moreover, a recent study has indicated that Gata-3 is required for the generation of ILC3s (128), before the identification of the CHILP (10). Transfer of Gata-3-deficient fetal liver precursor cells in mice lacking ILCs prevents reconstitution of all ROR $\gamma \mathrm{t}^{+}$ILC3s. This finding has led to the hypothesis that a common precursor might exist between ILC2s and ILC3s (128). In agreement with this view, another transcription factor TCF-1 (encoded by Tcf7) is required for ILC2s and NCR ${ }^{+}$ILC3s $(129,130)$. TCF1 in ILC2s acts downstream of Notch and forced expression of TCF-1 can bypass Notch requirement for ILC2 generation. TCF1 also induces Gata-3, which is responsible for upregulation of
Il-17rb (the receptor for IL-25) and Il2ra (CD25) in developing ILC2s. However, in the absence of Gata-3, TCF-1 directly controls the expression of $I l 7 r$ (CD127) (130). In $\mathrm{NCR}^{+}$ILC3s, TCF-1 acts downstream of Tbet and Notch to promote ILC3 development (129).

Gata-3 is also required to induce differentiation and/or maintenance of siLP ILC1s (10), as deletion of Gata-3 in NKp46 ${ }^{+}$cells results in a dramatic reduction of this ILC subset, while does not affect ILC3s or cNKs. In addition, early deletion of Gata-3 in hematopoietic cells abolishes the development of all $\mathrm{CD} 127^{+}$ ILCs (131).

While it is not clear whether TCF-1 is also required for siLP ILC1s, the data available suggest that some transcription factors may be required at multiple stages of ILC differentiation and may be turned on and off at different transitional steps with a hierarchy that is still poorly defined.

Intraepithelial ILC1s and cNKs cells share some requirements in transcription factors for their differentiation. To begin, both cell populations require Tbet for development $(9,132)$. In addition, Tbet is necessary for the development of liverresident NK cells that express Trail, CD49a, lack DX5, and Eomes (133) and have features of tissue-resident memory cells based on parabiosis experiments $(30,134)$. Although these cells were originally thought to represent an NK immature cell subset (135), more recent data suggest that they represent a distinct lineage of NK cells that share part of their transcriptional program with NKT cells (133). While it is not clear whether intraepithelial ILC1s derive from the CHILP, liverresident NK cells could represent a true subset of ILC1s related to the siLP ILC1s, since they appear to differentiate from the CHILP (10).

Intraepithelial ILC1s and cNK cells also require E4BP4 (encoded by Nfil3) to develop $(9,136,137)$. E4BP4 in NK cell development was previously thought to act directly downstream of IL-15R, which is required for NK cell maintenance $(138,139)$. However, more recent data suggest that viral infections can rescue NK cell development independently of E4BP4 in a process that requires inflammatory cytokines such as type 1 interferon and IL-12 along with ITAM signaling (140). E4BP4-independent NK cells are functional and persist in the periphery in an IL15 dependent fashion. Ablation of E4BP4 after the earlier steps of NK cell commitment completely bypasses the requirement for E4BP4 in NK cell development (140). In addition, E4BP4 is less stringently required for NK cell development outside of the bone marrow. Liver-resident Trail ${ }^{+}, \mathrm{DX}^{-} \mathrm{NK}$ cells develop in the absence of E4BP4, especially when T cell competition is eliminated $(30,141,142)$. Salivary gland NKs also do not require E4BP4 (29). The role for E4BP4 in thymic NK cell development is still controversial. Thymic NK cells seem to develop normally in vitro from E4BP4-deficient double negative (DN)1 and DN2 thymocytes (141). However, a second study indicates that thymic NKs in vivo develop along an E4BP4-dependent pathway (142). According to this report, E4BP4 is necessary to enforce Eomes expression in cNKs as well as in thymic NKs. Further confirming that E4BP4 may be necessary to drive Eomes expression, another report demonstrates that E4BP4 is strictly required for the transition from CLP to NK cell progenitor and regulates Eomes and 
Id2 expression in NK cells (143). Challenging the previous concept that E4BP4 acts downstream of the IL-15R (136), this study shows that E4BP4 operates upstream of IL-15 signaling and in the absence of E4BP4 CD122+ NK precursors fail to develop. E4BP4 expression is detected earlier that Tbet, Eomes, or Id2 expression and chromatin immunoprecipitation experiments demonstrate that E4BP4 promotes transcription of Eomes and Id2 by binding directly to the regulatory regions of their genes (143). These data are, however, in conflict with the study by Seillet et al., which shows that Id2 expression is normal in the absence of E4BP4 (142). Further studies will be necessary to elucidate the exact hierarchy in which transcription factors need to be expressed in order to grant successful development and maturation of NK cells and ILCs.

Finally, cNK cells share with $\mathrm{CD} 4^{+}$LTi-like cells the requirement for the HGM-box transcription factor superfamily member TOX. TOX-deficient animals lack NK cells and do not develop lymph nodes nor PP (144). Although it has been hypothesized that TOX controls induction or maintenance of Id2 in precursor cells, the exact mechanisms by which TOX regulates development of cNKs and LTi-like cells and whether it is necessary for other ILC subsets is unclear.

\section{CONCLUDING REMARIKS}

Studies over the past few years have indicated that adaptive immunity has adopted modules already established in the innate branch of the immune system to counteract pathogens and to maintain homeostasis at mucosal surfaces, which are constantly exposed to environmental insults and non-self-microbial communities. The identification of innate subsets that mimic Th1, Th2, and Th17/Th22 Thelper cells has greatly advanced our understanding of how immune responses are orchestrated and shaped. Future challenges in the field will be to understand whether additional subsets of ILCs are present that prevent or control autoimmune processes, i.e., whether an innate functional equivalent of regulatory $\mathrm{T}$ cells is in place. In addition, it will be important to delineate whether dedicated subsets of APCs or stromal cells are located in mucosal tissues that can preferentially activate a particular ILC group, or whether this activation process depends on specific signals provided by the intruder. Elucidating whether diverse inflammatory milieus can elicit different responses and immunological outcomes from the same ILC group will be also important. In the long term, a better understanding of the very first events that take place early on during the initiation of an immune response may be key in designing better strategies for vaccine development and therapeutic intervention.

\section{ACKNOWLEDGMENTS}

This work was supported by RO1 CA176695 and National Multiple Sclerosis Society grant RG4687A1/1 to Marina Cella. The authors thank Michelle Robinette for critical reading of the manuscript.

\section{REFERENCES}

1. Mucida D, Cheroutre H. The many face-lifts of CD4 T helper cells. Adv Immunol (2010) 107:139-52. doi:10.1016/B978-0-12-381300-8.00005-8

2. Yokoyama WM. Natural killer cell immune responses. Immunol Res (2005) 32:317-25. doi:10.1385/IR:32:1-3:317

3. Lanier LL. Up on the tightrope: natural killer cell activation and inhibition. Nat Immunol (2008) 9:495-502. doi:10.1038/ni1581
4. Chijioke O, Munz C. Dendritic cell derived cytokines in human natural killer cell differentiation and activation. Front Immunol (2013) 4:365. doi:10.3389/ fimmu.2013.00365

5. Spits H, Artis D, Colonna M, Diefenbach A, Di Santo JP, Eberl G, et al. Innate lymphoid cells - a proposal for uniform nomenclature. Nat Rev Immunol (2013) 13:145-9. doi:10.1038/nri3365

6. Sun JC, Lanier LL. NK cell development, homeostasis and function: parallels with CD8(+) T cells. Nat Rev Immunol (2011) 11:645-57. doi:10.1038/nri3044

7. Vivier E, Raulet DH, Moretta A, Caligiuri MA, Zitvogel L, Lanier LL, et al. Innate or adaptive immunity? The example of natural killer cells. Science (2011) 331:44-9. doi:10.1126/science.1198687

8. Bernink JH, Peters CP, Munneke M, te Velde AA, Meijer SL, Weijer K, et al. Human type 1 innate lymphoid cells accumulate in inflamed mucosal tissues. Nat Immunol (2013) 14:221-9. doi:10.1038/ni.2534

9. Fuchs A, Vermi W, Lee JS, Lonardi S, Gilfillan S, Newberry RD, et al. Intraepithelial type 1 innate lymphoid cells are a unique subset of IL-12- and IL-15-responsive IFN-gamma-producing cells. Immunity (2013) 38:769-81. doi:10.1016/j.immuni.2013.02.010

10. Klose CS, Flach M, Mohle L, Rogell L, Hoyler T, Ebert K, et al. Differentiation of type 1 ILCs from a common progenitor to all helper-like innate lymphoid cell lineages. Cell (2014) 157:340-56. doi:10.1016/j.cell.2014.03.030

11. Shi FD, Ljunggren HG, La Cava A, Van Kaer L. Organ-specific features of natural killer cells. Nat Rev Immunol (2011) 11:658-71. doi:10.1038/nri3065

12. Yu J, Freud AG, Caligiuri MA. Location and cellular stages of natural killer cell development. Trends Immunol (2013) 34:573-82. doi:10.1016/j.it.2013.07.005

13. Herberman RB, Nunn ME, Lavrin DH. Natural cytotoxic reactivity of mouse lymphoid cells against syngeneic acid allogeneic tumors. I. Distribution of reactivity and specificity. Int J Cancer (1975) 16:216-29. doi:10.1002/ijc. 2910160205

14. Kiessling R, Klein E, Pross H, Wigzell H. "Natural" killer cells in the mouse. II. Cytotoxic cells with specificity for mouse Moloney leukemia cells. Characteristics of the killer cell. Eur J Immunol (1975) 5:117-21. doi:10.1002/eji. 1830050208

15. Vidal SM, Khakoo SI, Biron CA. Natural killer cell responses during viral infections: flexibility and conditioning of innate immunity by experience. Curr Opin Virol (2011) 1:497-512. doi:10.1016/j.coviro.2011.10.017

16. Gross E, Sunwoo JB, Bui JD. Cancer immunosurveillance and immunoediting by natural killer cells. Cancer J (2013) 19:483-9. doi:10.1097/PPO. 0000000000000005

17. Marcus A, Gowen BG, Thompson TW, Iannello A, Ardolino M, Deng W, et al. Recognition of tumors by the innate immune system and natural killer cells. Adv Immunol (2014) 122:91-128. doi:10.1016/B978-0-12-800267-4.00003-1

18. Cooper MA, Fehniger TA, Fuchs A, Colonna M, Caligiuri MA. NK cell and DC interactions. Trends Immunol (2004) 25:47-52. doi:10.1016/j.it.2003.10.012

19. Fehniger TA, Cooper MA, Nuovo GJ, Cella M, Facchetti F, Colonna M, et al. CD56bright natural killer cells are present in human lymph nodes and are activated by T cell-derived IL-2: a potential new link between adaptive and innate immunity. Blood (2003) 101:3052-7. doi:10.1182/blood-2002-09-2876

20. De Maria A, Bozzano F, Cantoni C, Moretta L. Revisiting human natural killer cell subset function revealed cytolytic CD56(dim)CD16+ NK cells as rapid producers of abundant IFN-gamma on activation. Proc Natl Acad Sci U S A (2011) 108:728-32. doi:10.1073/pnas.1012356108

21. Chan A, Hong DL, Atzberger A, Kollnberger S, Filer AD, Buckley CD, et al. CD56bright human NK cells differentiate into CD56dim cells: role of contact with peripheral fibroblasts. J Immunol (2007) 179:89-94. doi:10.4049/ jimmunol.179.1.89

22. Romagnani C, Juelke K, Falco M, Morandi B, D’Agostino A, Costa R, et al. CD56brightCD16- killer Ig-like receptor- NK cells display longer telomeres and acquire features of CD56dim NK cells upon activation. J Immunol (2007) 178:4947-55. doi:10.4049/jimmunol.178.8.4947

23. Cooper MA, Fehniger TA, Turner SC, Chen KS, Ghaheri BA, Ghayur T, et al. Human natural killer cells: a unique innate immunoregulatory role for the CD56(bright) subset. Blood (2001) 97:3146-51. doi:10.1182/blood.V97.10. 3146

24. Campbell JJ, Qin S, Unutmaz D, Soler D, Murphy KE, Hodge MR, et al. Unique subpopulations of CD56+ NK and NK-T peripheral blood lymphocytes identified by chemokine receptor expression repertoire. JImmunol (2001) 166:6477-82. doi:10.4049/jimmunol.166.11.6477 
25. Hayakawa Y, Smyth MJ. CD27 dissects mature NK cells into two subsets with distinct responsiveness and migratory capacity. J Immunol (2006) 176:1517-24. doi:10.4049/jimmunol.176.3.1517

26. Vosshenrich CA, Garcia-Ojeda ME, Samson-Villeger SI, Pasqualetto V, Enault L, Richard-Le Goff O, et al. A thymic pathway of mouse natural killer cell development characterized by expression of GATA-3 and CD127. Nat Immunol (2006) 7:1217-24. doi:10.1038/ni1395

27. Yokoyama WM, Sojka DK, Peng H, Tian Z. Tissue-resident natural killer cells. Cold Spring Harb Symp Quant Biol (2014) LXXVIII. doi:10.1101/sqb. 2013.78.020354

28. Tessmer MS, Reilly EC, Brossay L. Salivary gland NK cells are phenotypically and functionally unique. PLoS Pathog (2011) 7:e1001254. doi:10.1371/journal. ppat. 1001254

29. Cortez VS, Fuchs A, Cella M, Gilfillan S, Colonna M. Cutting edge: salivary gland NK cells develop independently of Nfil3 in steady-state. JImmunol (2014) 192:4487-91. doi:10.4049/jimmunol.1303469

30. Sojka DK, Plougastel-Douglas B, Yang L, Pak-Wittel MA, Artyomov MN, Ivanova $\mathrm{Y}$, et al. Tissue-resident natural killer (NK) cells are cell lineages distinct from thymic and conventional splenic NK cells. Elife (2014) 3:e01659. doi:10.7554/eLife.01659

31. Cheng M, Charoudeh HN, Brodin P, Tang Y, Lakshmikanth T, Hoglund P, et al. Distinct and overlapping patterns of cytokine regulation of thymic and bone marrow-derived NK cell development. J Immunol (2009) 182:1460-8. doi:10.4049/jimmunol.182.3.1460

32. Yokoyama WM. Natural killer cell receptors. Curr Opin Immunol (1998) 10:298-305. doi:10.1016/S0952-7915(98)80168-4

33. Moretta L, Bottino C, Pende D, Castriconi R, Mingari MC, Moretta A. Surface NK receptors and their ligands on tumor cells. Semin Immunol (2006) 18:151-8. doi:10.1016/j.smim.2006.03.002

34. Stewart CA, Vivier E, Colonna M. Strategies of natural killer cell recognition and signaling. Curr Top Microbiol Immunol (2006) 298:1-21. doi:10.1007/3540-27743-9_1

35. Long EO, Kim HS, Liu D, Peterson ME, Rajagopalan S. Controlling natural killer cell responses: integration of signals for activation and inhibition. Annu Rev Immunol (2013) 31:227-58. doi:10.1146/annurev-immunol-020711-075005

36. Raulet DH, Guerra N. Oncogenic stress sensed by the immune system: role of natural killer cell receptors. Nat Rev Immunol (2009) 9:568-80. doi:10.1038/nri2604

37. Ljunggren HG, Karre K. In search of the "missing self": MHC molecules and NK cell recognition. Immunol Today (1990) 11:237-44. doi:10.1016/01675699(90)90097-S

38. Horng T, Bezbradica JS, Medzhitov R. NKG2D signaling is coupled to the interleukin 15 receptor signaling pathway. Nat Immunol (2007) 8:1345-52. doi:10.1038/ni1524

39. Elliott JM, Yokoyama WM. Unifying concepts of MHC-dependent natural killer cell education. Trends Immunol (2011) 32:364-72. doi:10.1016/j.it.2011. 06.001

40. Cooper MA, Yokoyama WM. Memory-like responses of natural killer cells. Immunol Rev (2010) 235:297-305. doi:10.1111/j.0105-2896.2010.00891.x

41. Shui JW, Larange A, Kim G, Vela JL, Zahner S, Cheroutre H, et al. HVEM signalling at mucosal barriers provides host defence against pathogenic bacteria. Nature (2012) 488:222-5. doi:10.1038/nature11242

42. DePaolo RW, Abadie V, Tang F, Fehlner-Peach H, Hall JA, Wang W, et al. Coadjuvant effects of retinoic acid and IL-15 induce inflammatory immunity to dietary antigens. Nature (2011) 471:220-4. doi:10.1038/nature09849

43. Schulthess J, Meresse B, Ramiro-Puig E, Montcuquet N, Darche S, Begue B, et al. Interleukin-15-dependent NKp46+ innate lymphoid cells control intestinal inflammation by recruiting inflammatory monocytes. Immunity (2012) 37:108-21. doi:10.1016/j.immuni.2012.05.013

44. Cella M, Otero K, Colonna M. Expansion of human NK-22 cells with IL-7, IL-2, and IL-1beta reveals intrinsic functional plasticity. Proc Natl Acad Sci U S A (2010) 107:10961-6. doi:10.1073/pnas.1005641107

45. Vonarbourg C, Mortha A, Bui VL, Hernandez PP, Kiss EA, Hoyler T, et al. Regulated expression of nuclear receptor RORgammat confers distinct functional fates to NK cell receptor-expressing RORgammat(+) innate lymphocytes. Immunity (2010) 33:736-51. doi:10.1016/j.immuni.2010.10.017

46. Klose CS, Kiss EA, Schwierzeck V, Ebert K, Hoyler T, D'Hargues Y, et al. A T-bet gradient controls the fate and function of CCR6-RORgammat+ innate lymphoid cells. Nature (2013) 494:261-5. doi:10.1038/nature11813
47. Moro K, Yamada T, Tanabe M, Takeuchi T, Ikawa T, Kawamoto H, et al. Innate production of $\mathrm{T}(\mathrm{H}) 2$ cytokines by adipose tissue-associated c-Kit $(+) \mathrm{Sca}-1(+)$ lymphoid cells. Nature (2010) 463:540-4. doi:10.1038/nature08636

48. Neill DR, Wong SH, Bellosi A, Flynn RJ, Daly M, Langford TK, et al. Nuocytes represent a new innate effector leukocyte that mediates type-2 immunity. Nature (2010) 464:1367-70. doi:10.1038/nature08900

49. Price AE, Liang HE, Sullivan BM, Reinhardt RL, Eisley CJ, Erle DJ, et al. Systemically dispersed innate IL-13-expressing cells in type 2 immunity. Proc Natl Acad Sci U S A (2010) 107:11489-94. doi:10.1073/pnas.1003988107

50. Saenz SA, Siracusa MC, Monticelli LA, Ziegler CG, Kim BS, Brestoff JR, et al. IL25 simultaneously elicits distinct populations of innate lymphoid cells and multipotent progenitor type 2 (MPPtype2) cells. J Exp Med (2013) 210:1823-37. doi:10.1084/jem.20122332

51. Turner JE, Morrison PJ, Wilhelm C, Wilson M, Ahlfors H, Renauld JC, et al. IL-9-mediated survival of type 2 innate lymphoid cells promotes damage control in helminth-induced lung inflammation. J Exp Med (2013) 210:2951-65. doi:10.1084/jem.20130071

52. Halim TY, Krauss RH, Sun AC, Takei F. Lung natural helper cells are a critical source of Th2 cell-type cytokines in protease allergen-induced airway inflammation. Immunity (2012) 36:451-63. doi:10.1016/j.immuni.2011.12.020

53. Imai Y, Yasuda K, Sakaguchi Y, Haneda T, Mizutani H, Yoshimoto T, et al. Skinspecific expression of IL-33 activates group 2 innate lymphoid cells and elicits atopic dermatitis-like inflammation in mice. Proc Natl Acad Sci U S A (2013) 110:13921-6. doi:10.1073/pnas.1307321110

54. Roediger B, Kyle R, Yip KH, Sumaria N, Guy TV, Kim BS, et al. Cutaneous immunosurveillance and regulation of inflammation by group 2 innate lymphoid cells. Nat Immunol (2013) 14:564-73. doi:10.1038/ni.2584

55. Salimi M, Barlow JL, Saunders SP, Xue L, Gutowska-Owsiak D, Wang X, et al. A role for IL-25 and IL-33-driven type-2 innate lymphoid cells in atopic dermatitis. J Exp Med (2013) 210:2939-50. doi:10.1084/jem.20130351

56. Fallon PG, Ballantyne SJ, Mangan NE, Barlow JL, Dasvarma A, Hewett DR, et al. Identification of an interleukin (IL)-25-dependent cell population that provides IL-4, IL-5, and IL-13 at the onset of helminth expulsion. J Exp Med (2006) 203:1105-16. doi:10.1084/jem.20051615

57. Walker JA, McKenzie AN. Development and function of group 2 innate lymphoid cells. Curr Opin Immunol (2013) 25:148-55. doi:10.1016/j.coi.2013.02. 010

58. Monticelli LA, Sonnenberg GF, Abt MC, Alenghat T, Ziegler CG, Doering TA, et al. Innate lymphoid cells promote lung-tissue homeostasis after infection with influenza virus. Nat Immunol (2011) 12:1045-54. doi:10.1031/ni.2131

59. Chang YJ, Kim HY, Albacker LA, Baumgarth N, McKenzie AN, Smith DE, et al. Innate lymphoid cells mediate influenza-induced airway hyper-reactivity independently of adaptive immunity. Nat Immunol (2011) 12:631-8. doi:10.1038/ ni. 2045

60. Molofsky AB, Nussbaum JC, Liang HE, Van Dyken SJ, Cheng LE, Mohapatra $\mathrm{A}$, et al. Innate lymphoid type 2 cells sustain visceral adipose tissue eosinophils and alternatively activated macrophages. J Exp Med (2013) 210:535-49. doi:10.1084/jem.20121964

61. Nussbaum JC, Van Dyken SJ, von Moltke J, Cheng LE, Mohapatra A, Molofsky AB, et al. Type 2 innate lymphoid cells control eosinophil homeostasis. Nature (2013) 502:245-8. doi:10.1038/nature12526

62. Kim BS, Siracusa MC, Saenz SA, Noti M, Monticelli LA, Sonnenberg GF, et al. TSLP elicits IL-33-independent innate lymphoid cell responses to promote skin inflammation. Sci Transl Med (2013) 5:170ra116. doi:10.1126/scitranslmed. 3005374

63. Mjosberg JM, Trifari S, Crellin NK, Peters CP, van Drunen CM, Piet B, et al. Human IL-25- and IL-33-responsive type 2 innate lymphoid cells are defined by expression of CRTH2 and CD161. Nat Immunol (2011) 12:1055-62. doi:10.1038/ni.2104

64. Zenewicz LA, Yancopoulos GD, Valenzuela DM, Murphy AJ, Stevens S, Flavell RA. Innate and adaptive interleukin-22 protects mice from inflammatory bowel disease. Immunity (2008) 29:947-57. doi:10.1016/j.immuni.2008.11.003

65. Cella M, Fuchs A, Vermi W, Facchetti F, Otero K, Lennerz JK, et al. A human natural killer cell subset provides an innate source of IL-22 for mucosal immunity. Nature (2009) 457:722-5. doi:10.1038/nature07537

66. Hughes T, Becknell B, McClory S, Briercheck E, Freud AG, Zhang X, et al. Stage 3 immature human natural killer cells found in secondary lymphoid tissue constitutively and selectively express the TH 17 cytokine interleukin-22. Blood (2009) 113:4008-10. doi:10.1182/blood-2008-12-192443 
67. Luci C, Reynders A, Ivanov II, Cognet C, Chiche L, Chasson L, et al. Influence of the transcription factor RORgammat on the development of NKp46+ cell populations in gut and skin. Nat Immunol (2009) 10:75-82. doi:10.1038/ni. 1681

68. Sanos SL, Bui VL, Mortha A, Oberle K, Heners C, Johner C, et al. RORgammat and commensal microflora are required for the differentiation of mucosal interleukin 22-producing NKp46+ cells. Nat Immunol (2009) 10:83-91. doi:10.1038/ni.1684

69. Satoh-Takayama N, Dumoutier L, Lesjean-Pottier S, Ribeiro VS, Mandelboim $\mathrm{O}$, Renauld JC, et al. The natural cytotoxicity receptor NKp46 is dispensable for IL-22-mediated innate intestinal immune defense against Citrobacter rodentium. J Immunol (2009) 183:6579-87. doi:10.4049/jimmunol.0901935

70. Mebius RE, Streeter PR, Michie S, Butcher EC, Weissman IL. A developmental switch in lymphocyte homing receptor and endothelial vascular addressin expression regulates lymphocyte homing and permits CD4+ CD3cells to colonize lymph nodes. Proc Natl Acad Sci U S A (1996) 93:11019-24. doi:10.1073/pnas.93.20.11019

71. Buonocore S, Ahern PP, Uhlig HH, Ivanov II, Littman DR, Maloy KJ, et al. Innate lymphoid cells drive interleukin-23-dependent innate intestinal pathology. Nature (2010) 464:1371-5. doi:10.1038/nature08949

72. Hughes T, Becknell B, Freud AG, McClory S, Briercheck E, Yu J, et al. Interleukin-1beta selectively expands and sustains interleukin-22+ immature human natural killer cells in secondary lymphoid tissue. Immunity (2010) 32:803-14. doi:10.1016/j.immuni.2010.06.007

73. Takatori H, Kanno Y, Watford WT, Tato CM, Weiss G, Ivanov II, et al. Lymphoid tissue inducer-like cells are an innate source of IL-17 and IL-22. J Exp Med (2009) 206:35-41. doi:10.1084/jem.20072713

74. Kim HY, Lee HJ, Chang YJ, Pichavant M, Shore SA, Fitzgerald KA, et al. Interleukin-17-producing innate lymphoid cells and the NLRP3 inflammasome facilitate obesity-associated airway hyperreactivity. Nat Med (2014) 20:54-61. doi:10.1038/nm.3423

75. Zheng Y, Valdez PA, Danilenko DM, Hu Y, Sa SM, Gong Q, et al. Interleukin-22 mediates early host defense against attaching and effacing bacterial pathogens. Nat Med (2008) 14:282-9. doi:10.1038/nm1720

76. Zenewicz LA, Yancopoulos GD, Valenzuela DM, Murphy AJ, Karow M, Flavell RA. Interleukin-22 but not interleukin-17 provides protection to hepatocytes during acute liver inflammation. Immunity (2007) 27:647-59. doi:10.1016/j. immuni.2007.07.023

77. Sonnenberg GF, Monticelli LA, Alenghat T, Fung TC, Hutnick NA, Kunisawa J, et al. Innate lymphoid cells promote anatomical containment of lymphoidresident commensal bacteria. Science (2012) 336:1321-5. doi:10.1126/science. 1222551

78. Hanash AM, Dudakov JA, Hua G, O’Connor MH, Young LF, Singer NV, et al. Interleukin-22 protects intestinal stem cells from immune-mediated tissue damage and regulates sensitivity to graft versus host disease. Immunity (2012) 37:339-50. doi:10.1016/j.immuni.2012.05.028

79. Huber S, Gagliani N, Zenewicz LA, Huber FJ, Bosurgi L, Hu B, et al. IL-22BP is regulated by the inflammasome and modulates tumorigenesis in the intestine. Nature (2012) 491:259-63. doi:10.1038/nature11535

80. Kirchberger S, Royston DJ, Boulard O, Thornton E, Franchini F, Szabady $\mathrm{RL}$, et al. Innate lymphoid cells sustain colon cancer through production of interleukin-22 in a mouse model. J Exp Med (2013) 210(5):917-31. doi:10.1084/jem.20122308

81. Geremia A, Arancibia-Carcamo CV, Fleming MP, Rust N, Singh B, Mortensen NJ, et al. IL-23-responsive innate lymphoid cells are increased in inflammatory bowel disease. J Exp Med (2011) 208:1127-33. doi:10.1084/jem.20101712

82. Villanova F, Flutter B, Tosi I, Grys K, Sreeneebus H, Perera GK, et al. Characterization of innate lymphoid cells in human skin and blood demonstrates increase of NKp44+ ILC3 in psoriasis. J Invest Dermatol (2013) 134(4):984-91. doi:10.1038/jid.2013.477

83. Hepworth MR, Monticelli LA, Fung TC, Ziegler CG, Grunberg S, Sinha R, et al. Innate lymphoid cells regulate CD4+ T-cell responses to intestinal commensal bacteria. Nature (2013) 498:113-7. doi:10.1038/nature12240

84. Griseri T, McKenzie BS, Schiering C, Powrie F. Dysregulated hematopoietic stem and progenitor cell activity promotes interleukin-23-driven chronic intestinal inflammation. Immunity (2012) 37:1116-29. doi:10.1016/j.immuni. 2012.08.025
85. Mortha A, Chudnovskiy A, Hashimoto D, Bogunovic M, Spencer SP, Belkaid Y, et al. Microbiota-dependent crosstalk between macrophages and ILC3 promotes intestinal homeostasis. Science (2014) 343:1249288. doi:10.1126/science. 1249288

86. Magri G, Miyajima M, Bascones S, Mortha A, Puga I, Cassis L, et al. Innate lymphoid cells integrate stromal and immunological signals to enhance antibody production by splenic marginal zone B cells. Nat Immunol (2014) 15(4):354-64. doi:10.1038/ni.2830

87. Tsuji M, Suzuki K, Kitamura H, Maruya M, Kinoshita K, Ivanov II, et al. Requirement for lymphoid tissue-inducer cells in isolated follicle formation and $\mathrm{T}$ cell-independent immunoglobulin A generation in the gut. Immunity (2008) 29:261-71. doi:10.1016/j.immuni.2008.05.014

88. Kruglov AA, Grivennikov SI, Kuprash DV, Winsauer C, Prepens S, Seleznik GM, et al. Nonredundant function of soluble LTalpha3 produced by innate lymphoid cells in intestinal homeostasis. Science (2013) 342:1243-6. doi:10. 1126/science. 1243364

89. Knoop KA, Kumar N, Butler BR, Sakthivel SK, Taylor RT, Nochi T, et al. RANKL is necessary and sufficient to initiate development of antigen-sampling $M$ cells in the intestinal epithelium. J Immunol (2009) 183:5738-47. doi:10.4049/ jimmunol.0901563

90. Behnsen J, Jellbauer S, Wong CP, Edwards RA, George MD, Ouyang W, et al. The cytokine IL-22 promotes pathogen colonization by suppressing related commensal bacteria. Immunity (2014) 40:262-73. doi:10.1016/j.immuni.2014.01. 003

91. Spencer SP, Wilhelm C, Yang Q, Hall JA, Bouladoux N, Boyd A, et al. Adaptation of innate lymphoid cells to a micronutrient deficiency promotes type 2 barrier immunity. Science (2014) 343:432-7. doi:10.1126/science.1247606

92. van de Pavert SA, Ferreira M, Domingues RG, Ribeiro H, Molenaar R, MoreiraSantos L, et al. Maternal retinoids control type 3 innate lymphoid cells and set the offspring immunity. Nature (2014) 508:123-7. doi:10.1038/nature13158

93. Yokota Y, Mansouri A, Mori S, Sugawara S, Adachi S, Nishikawa S, et al. Development of peripheral lymphoid organs and natural killer cells depends on the helix-loop-helix inhibitor Id2. Nature (1999) 397:702-6. doi:10.1038/17812

94. Hoyler T, Klose CS, Souabni A, Turqueti-Neves A, Pfeifer D, Rawlins EL, et al. The transcription factor GATA-3 controls cell fate and maintenance of type 2 innate lymphoid cells. Immunity (2012) 37:634-48. doi:10.1016/j.immuni. 2012.06.020

95. Boos MD, Yokota Y, Eberl G, Kee BL. Mature natural killer cell and lymphoid tissue-inducing cell development requires Id2-mediated suppression of E protein activity. J Exp Med (2007) 204:1119-30. doi:10.1084/jem.20061959

96. Thal MA, Carvalho TL, He T, Kim HG, Gao H, Hagman J, et al. Ebfl-mediated down-regulation of Id 2 and Id 3 is essential for specification of the B cell lineage. Proc Natl Acad Sci U S A (2009) 106:552-7. doi:10.1073/pnas.0802550106

97. Nechanitzky R, Akbas D, Scherer S, Gyory I, Hoyler T, Ramamoorthy S, et al. Transcription factor EBF1 is essential for the maintenance of B cell identity and prevention of alternative fates in committed cells. Nat Immunol (2013) 14:867-75. doi:10.1038/ni.2641

98. Constantinides MG, McDonald BD, Verhoef PA, Bendelac A. A committed precursor to innate lymphoid cells. Nature (2014) 508(7496):397-401. doi:10.1038/nature13047

99. Savage AK, Constantinides MG, Han J, Picard D, Martin E, Li B, et al. The transcription factor PLZF directs the effector program of the NKT cell lineage. Immunity (2008) 29:391-403. doi:10.1016/j.immuni.2008.07.011

100. Verykokakis M, Krishnamoorthy V, Iavarone A, Lasorella A, Sigvardsson M, Kee BL. Essential functions for ID proteins at multiple checkpoints in invariant NKT cell development. J Immunol (2013) 191:5973-83. doi:10.4049/ jimmunol.1301521

101. Dong C. Genetic controls of Th17 cell differentiation and plasticity. Exp Mol Med (2011) 43:1-6. doi:10.3858/emm.2011.43.1.007

102. Zuniga LA, Jain R, Haines C, Cua DJ. Th17 cell development: from the cradle to the grave. Immunol Rev (2013) 252:78-88. doi:10.1111/imr.12036

103. Eberl G, Littman DR. The role of the nuclear hormone receptor RORgammat in the development of lymph nodes and Peyer's patches. Immunol Rev (2003) 195:81-90. doi:10.1034/j.1600-065X.2003.00074.x

104. Eberl G, Marmon S, Sunshine MJ, Rennert PD, Choi Y, Littman DR. An essential function for the nuclear receptor RORgamma(t) in the generation of fetal lymphoid tissue inducer cells. Nat Immunol (2004) 5:64-73. doi:10.1038/ni1022 
105. Bouskra D, Brezillon C, Berard M, Werts C, Varona R, Boneca IG, et al. Lymphoid tissue genesis induced by commensals through NOD1 regulates intestinal homeostasis. Nature (2008) 456:507-10. doi:10.1038/nature07450

106. Kiss EA, Vonarbourg C, Kopfmann S, Hobeika E, Finke D, Esser C, et al. Natural aryl hydrocarbon receptor ligands control organogenesis of intestinal lymphoid follicles. Science (2011) 334:1561-5. doi:10.1126/science.1214914

107. Lee JS, Cella M, Colonna M. AHR and the transcriptional regulation of type17/22 ILC. Front Immunol (2012) 3:10. doi:10.3389/fimmu.2012.00010

108. Qiu J, Heller JJ, Guo X, Chen ZM, Fish K, Fu YX, et al. The aryl hydrocarbon receptor regulates gut immunity through modulation of innate lymphoid cells. Immunity (2012) 36:92-104. doi:10.1016/j.immuni.2011.11.011

109. Quintana FJ, Basso AS, Iglesias AH, Korn T, Farez MF, Bettelli E, et al. Control of $\mathrm{T}(\mathrm{reg})$ and $\mathrm{T}(\mathrm{H}) 17$ cell differentiation by the aryl hydrocarbon receptor. Nature (2008) 453:65-71. doi:10.1038/nature06880

110. Veldhoen M, Hirota K, Westendorf AM, Buer J, Dumoutier L, Renauld JC, et al. The aryl hydrocarbon receptor links TH17-cell-mediated autoimmunity to environmental toxins. Nature (2008) 453:106-9. doi:10.1038/nature06881

111. Lee JS, Cella M, McDonald KG, Garlanda C, Kennedy GD, Nukaya M, et al. AHR drives the development of gut ILC22 cells and postnatal lymphoid tissues via pathways dependent on and independent of Notch. Nat Immunol (2012) 13:144-51. doi:10.1038/ni.2187

112. Li Y, Innocentin S, Withers DR, Roberts NA, Gallagher AR, Grigorieva EF, et al. Exogenous stimuli maintain intraepithelial lymphocytes via aryl hydrocarbon receptor activation. Cell (2011) 147:629-40. doi:10.1016/j.cell.2011.09.025

113. Zelante T, Iannitti RG, Cunha C, De Luca A, Giovannini G, Pieraccini G, et al. Tryptophan catabolites from microbiota engage Aryl hydrocarbon receptor and balance mucosal reactivity via interleukin-22. Immunity (2013) 39:372-85. doi:10.1016/j.immuni.2013.08.003

114. Opitz CA, Litzenburger UM, Sahm F, Ott M, Tritschler I, Trump S, et al. An endogenous tumour-promoting ligand of the human aryl hydrocarbon receptor. Nature (2011) 478:197-203. doi:10.1038/nature10491

115. Qiu J, Guo X, Chen ZM, He L, Sonnenberg GF, Artis D, et al. Group 3 innate lymphoid cells inhibit T-cell-mediated intestinal inflammation through aryl hydrocarbon receptor signaling and regulation of microflora. Immunity (2013) 39:386-99. doi:10.1016/j.immuni.2013.08.002

116. Rankin LC, Groom JR, Chopin M, Herold MJ, Walker JA, Mielke LA, et al. The transcription factor T-bet is essential for the development of NKp46+ innate lymphocytes via the Notch pathway. Nat Immunol (2013) 14:389-95. doi:10.1038/ni.2545

117. Possot C, Schmutz S, Chea S, Boucontet L, Louise A, Cumano A, et al. Notch signaling is necessary for adult, but not fetal, development of RORgammat $(+)$ innate lymphoid cells. Nat Immunol (2011) 12:949-58. doi:10.1038/ni.2105

118. Sawa S, Cherrier M, Lochner M, Satoh-Takayama N, Fehling HJ, Langa F, et al. Lineage relationship analysis of RORgammat+ innate lymphoid cells. Science (2010) 330:665-9. doi:10.1126/science.1194597

119. Powell N, Walker AW, Stolarczyk E, Canavan JB, Gokmen MR, Marks E, et al. The transcription factor T-bet regulates intestinal inflammation mediated by interleukin-7 receptor+ innate lymphoid cells. Immunity (2012) 37:674-84. doi:10.1016/j.immuni.2012.09.008

120. Sciume G, Hirahara K, Takahashi H, Laurence A, Villarino AV, Singleton KL, et al. Distinct requirements for T-bet in gut innate lymphoid cells. J Exp Med (2012) 209:2331-8. doi:10.1084/jem.20122097

121. Ahn YO, Blazar BR, Miller JS, Verneris MR. Lineage relationships of human interleukin-22-producing CD56+ RORgammat+ innate lymphoid cells and conventional natural killer cells. Blood (2013) 121:2234-43. doi:10.1182/ blood-2012-07-440099

122. Glatzer T, Killig M, Meisig J, Ommert I, Luetke-Eversloh M, Babic M, et al. RORgammat(+) innate lymphoid cells acquire a proinflammatory program upon engagement of the activating receptor NKp44. Immunity (2013) 38:1223-35. doi:10.1016/j.immuni.2013.05.013

123. Guo X, Qiu J, Tu T, Yang X, Deng L, Anders RA, et al. Induction of innate lymphoid cell-derived interleukin-22 by the transcription factor STAT3 mediates protection against intestinal infection. Immunity (2014) 40:25-39. doi:10.1016/j.immuni.2013.10.021

124. Halim TY, Maclaren A, Romanish MT, Gold MJ, McNagny KM, Takei F. Retinoic-acid-receptor-related orphan nuclear receptor alpha is required for natural helper cell development and allergic inflammation. Immunity (2012) 37:463-74. doi:10.1016/j.immuni.2012.06.012
125. Spooner CJ, Lesch J, Yan D, Khan AA, Abbas A, Ramirez-Carrozzi V, et al. Specification of type 2 innate lymphocytes by the transcriptional determinant Gfil. Nat Immunol (2013) 14:1229-36. doi:10.1038/ni.2743

126. Mjosberg J, Bernink J, Golebski K, Karrich JJ, Peters CP, Blom B, et al. The transcription factor GATA3 is essential for the function of human type 2 innate lymphoid cells. Immunity (2012) 37:649-59. doi:10.1016/j.immuni.2012.08. 015

127. Klein Wolterink RG, Serafini N, van Nimwegen M, Vosshenrich CA, de Bruijn MJ, Fonseca Pereira D, et al. Essential, dose-dependent role for the transcription factor Gata3 in the development of IL-5+ and IL-13+ type 2 innate lymphoid cells. Proc Natl Acad Sci U S A (2013) 110:10240-5. doi:10.1073/pnas. 1217158110

128. Serafini N, Klein Wolterink RG, Satoh-Takayama N, Xu W, Vosshenrich CA, Hendriks RW, et al. Gata3 drives development of RORgammat+ group 3 innate lymphoid cells. J Exp Med (2014) 211:199-208. doi:10.1084/jem.20131038

129. Mielke LA, Groom JR, Rankin LC, Seillet C, Masson F, Putoczki T, et al. TCF-1 controls ILC2 and NKp46+RORgammat+ innate lymphocyte differentiation and protection in intestinal inflammation. J Immunol (2013) 191:4383-91. doi:10.4049/jimmunol.1301228

130. Yang Q, Monticelli LA, Saenz SA, Chi AW, Sonnenberg GF, Tang J, et al. T cell factor 1 is required for group 2 innate lymphoid cell generation. Immunity (2013) 38:694-704. doi:10.1016/j.immuni.2012.12.003

131. Yagi R, Zhong C, Northrup DL, Yu F, Bouladoux N, Spencer S, et al. The transcription factor GATA3 is critical for the development of all IL-7Ralphaexpressing innate lymphoid cells. Immunity (2014) 40:378-88. doi:10.1016/j. immuni.2014.01.012

132. Townsend MJ, Weinmann AS, Matsuda JL, Salomon R, Farnham PJ, Biron CA, et al. T-bet regulates the terminal maturation and homeostasis of $\mathrm{NK}$ and Valpha14i NKT cells. Immunity (2004) 20:477-94. doi:10.1016/S1074-7613(04) 00076-7

133. Daussy C, Faure F, Mayol K, Viel S, Gasteiger G, Charrier E, et al. T-bet and Eomes instruct the development of two distinct natural killer cell lineages in the liver and in the bone marrow. J Exp Med (2014) 211(3):563-77. doi:10.1084/jem.20131560

134. Peng H, Jiang X, Chen Y, Sojka DK, Wei H, Gao X, et al. Liver-resident NK cells confer adaptive immunity in skin-contact inflammation. J Clin Invest (2013) 123:1444-56. doi:10.1172/JCI66381

135. Gordon SM, Chaix J, Rupp LJ, Wu J, Madera S, Sun JC, et al. The transcription factors T-bet and Eomes control key checkpoints of natural killer cell maturation. Immunity (2012) 36:55-67. doi:10.1016/j.immuni.2011.11. 016

136. Gascoyne DM, Long E, Veiga-Fernandes H, de Boer J, Williams O, Seddon B, et al. The basic leucine zipper transcription factor E4BP4 is essential for natural killer cell development. Nat Immunol (2009) 10:1118-24. doi:10.1038/ni.1787

137. Kamizono S, Duncan GS, Seidel MG, Morimoto A, Hamada K, Grosveld G, et al. Nfil3/E4bp4 is required for the development and maturation of NK cells in vivo. J Exp Med (2009) 206:2977-86. doi:10.1084/jem.20092176

138. Lodolce J, Burkett P, Koka R, Boone D, Chien M, Chan F, et al. Interleukin-15 and the regulation of lymphoid homeostasis. Mol Immunol (2002) 39:537-44. doi:10.1016/S0161-5890(02)00211-0

139. Ranson T, Vosshenrich CA, Corcuff E, Richard O, Muller W, Di Santo JP. IL15 is an essential mediator of peripheral NK-cell homeostasis. Blood (2003) 101:4887-93. doi:10.1182/blood-2002-11-3392

140. Firth MA, Madera S, Beaulieu AM, Gasteiger G, Castillo EF, Schluns KS, et al. Nfil3-independent lineage maintenance and antiviral response of natural killer cells. J Exp Med (2013) 210:2981-90. doi:10.1084/jem.20130417

141. Crotta S, Gkioka A, Male V, Duarte JH, Davidson S, Nisoli I, et al. The transcription factor E4BP4 is not required for extramedullary pathways of NK cell development. J Immunol (2014) 192(6):2677-88. doi:10.4049/jimmunol. 1302765

142. Seillet C, Huntington ND, Gangatirkar P, Axelsson E, Minnich M, Brady HJ, et al. Differential requirement for Nfil 3 during NK cell development. J Immunol (2014) 192(6):2667-76. doi:10.4049/jimmunol.1302605

143. Male V, Nisoli I, Kostrzewski T, Allan DS, Carlyle JR, Lord GM, et al. The transcription factor E4bp4/Nfil3 controls commitment to the NK lineage and directly regulates Eomes and Id2 expression. J Exp Med (2014) 211:635-42. doi:10.1084/jem.20132398 
144. Aliahmad P, de la Torre B, Kaye J. Shared dependence on the DNA-binding factor TOX for the development of lymphoid tissue-inducer cell and NK cell lineages. Nat Immunol (2010) 11:945-52. doi:10.1038/ni.1930

Conflict of Interest Statement: The authors declare that the research was conducted in the absence of any commercial or financial relationships that could be construed as a potential conflict of interest.

Received: 03 March 2014; accepted: 30 May 2014; published online: 16 June 2014.
Citation: Cella M, Miller H and Song C (2014) Beyond NK cells: the expanding universe of innate lymphoid cells. Front. Immunol. 5:282. doi: 10.3389/fimmu.2014.00282 This article was submitted to NK Cell Biology, a section of the journal Frontiers in Immunology.

Copyright (C) 2014 Cella, Miller and Song. This is an open-access article distributed under the terms of the Creative Commons Attribution License (CC BY). The use, distribution or reproduction in other forums is permitted, provided the original author (s) or licensor are credited and that the original publication in this journal is cited, in accordance with accepted academic practice. No use, distribution or reproduction is permitted which does not comply with these terms. 